\title{
Productivity of Czech Milk Production in European Comparison
}

\author{
Zdeňka Žáková Kroupová, Pavlína Hálová, Lenka Rumánková
}

Department of Economics, Faculty of Economics and Management, Czech University of Life Sciences Prague, Czech Republic

\begin{abstract}
The aim of the paper is to evaluate the development and main characteristics of Czech milk production productivity and to compare Czech development with the situation in the European Union. From a methodological point of view, a parametric approach in the form of stochastic frontier analysis was applied, the input distance function was estimated, and total factor productivity was examined. The analysis used an unbalanced panel data set, which describes TF14-45 specialist milk production from 27 member states of the European Union in the period 2004-2016 collected in the FADN database.

The results showed that in the Czech Republic, the average value of technical efficiency was $94.01 \%$ during the analysed time period. Compared to EU member states, this figure was above the EU-13 average (93.71\%). Czech milk production in the analysed period and the milk production of almost all other EU countries was characterized by increasing returns to scale. Examination of total factor productivity (TFP) showed that the scale effect and technical efficiency change effect can be considered the main components of TFP changes in Czech milk production. However, the scale effect was more significant in EU-15 countries than the Czech milk sector.
\end{abstract}

\section{Keywords}

Milk, Czech Republic, European Union, technical efficiency, random parameter model, total factor productivity.

Žáková Kroupová, Z., Hálová, P. and Rumánková, L. (2020) "Productivity of Czech Milk Production in European Comparison", A GRIS on-line Papers in Economics and Informatics, Vol. 12, No. 3, pp. 115-127. ISSN 1804-1930. DOI 10.7160/aol.2020.120310.

\section{Introduction}

According to the FADN database, milk production in the Czech Republic represents half of animal production and almost one fifth of the total agricultural production. Milk can be considered one of the most important agricultural commodities from a Czech and EU point of view. The importance of milk production is also obvious in the number of studies and scientific papers examining productivity in the dairy production process. These papers have analysed total factor productivity (TFP) development. Total factor productivity can also be broken down into partial components, including scale effect (SEC), technical efficiency change effect (TEC) and technical change effect (TC). The effect of these individual partial components has also been analysed and interpreted. Technical efficiency (TE) is especially interesting to researchers who analyse dairy production productivity.

The current studies focusing on milk productivity in EU countries have provided different results for some aspects of the dairy sector and the same results for other aspects of milk production. Skevas et al. (2018) showed that technical efficiency at German dairy producers has declined over time and the change in productivity has been driven by technological change. By contrast, Lansink et al. (2015) and Dakpo et al. (2019) concluded that the productivity of Dutch and French dairy farms has increased as a result of improvements intechnicalefficiency. Čechuraetal.(2017)concluded that the EU-15 (Old Member States) have a higher TFP than the EU-13 (New Member States) group. The EU-15 is also characterised by above-average TFP growth (Wojciechowski, 2017). Madau et al. (2017) confirmed that decreasing productivity at European dairy producers was mainly a result of technological regression. Changes in technical efficiency have had a positive effect on TFP in most EU countries. Špička and Machek (2015) showed that regions with a positive change in TE have a higher milk yield and higher long-term loans than regions with adverse changes in TE. Investment has therefore slowed down the decline in TE. 
The results of studies focusing on dairy milk productivity have predominantly concluded that the increase in milk productivity has been driven mainly by technological change, i.e. growth in productivity has been supported by modernization and innovation. From the perspective of individual countries, the prevailing effect of technological change can be seen in the Czech Republic, Estonia, Belgium, Hungary, Italy, Sweden, Finland and Ireland. The results of German and Dutch farms are questionable. According to Zhu and Lansink (2009), technical efficiency in these countries contributed more significantly to the change in TFP than technological change, whose impact has been emphasized in other studies.

Analysis of productivity also lets us evaluate the convergence of the EU-15 and EU-13 member states. However, some studies have shown quicker growth in TFP in the EU-15 Member States than its development in EU-13 Member States (Čechura et al., 2017; Irz and Jansik, 2015). This suggests the economic benefits of EU-13 integration have not yet been achieved. According to Čechura et al. (2017), only a few regions, mainly in the Czech Republic, Slovakia and Hungary, have achieved sufficient growth in total factor productivity to reach the more competitive EU-15 Member States. Most of these studies were based on the data set collected from the Farm Accountancy Data Network (FADN) database for the period 1990-2015.

From a methodological point of view, the parametric approach or stochastic frontier analysis (SFA) predominate in studies of TFP. In particular, the translogarithmic output-oriented distance function (ODF) has been estimated, even though the period of analysis covers milk production quota regulation, where the goal of maximizing profit through output growth cannot be fully met. Newman and Matthews (2007) and Skevas, Emvalomatis and Brümmer (2018) argued that output may not be fully regulated by quotas if manufacturers can trade or rent the quota freely. Some studies analysing the effect of milk quotas, for example, Barnes (2008), Kumbhakar et al. (2008), Žáková Kroupová (2016), however, respected the aforementioned limitations and applied the input-oriented distance function (IDF).

Some studies of total factor productivity have also focused on the relationship between the characteristics of production units, especially farm size, specialization, intensification and productivity and its components. The impact of agricultural policy has also been analysed in terms of deregulation of the quota system as well as subsidy policy.
The analyses were usually based on statistically testing the equality of mean values using the t-test or its non-parametric analogy in the case of violation of the normality presumption. Alternatively, regression analysis may also be used, including logistic regression (e.g., Bokusheva and Čechura (2017), study of the cereal production sector). Analysis of the difference in growth in total factor productivity in terms of specialization is particularly relevant in EU-13 member states, where mixed farms are also significantly involved in milk production. Žáková Kroupová (2016) found that TFP growth at specialized Czech farms was greater than at mixed dairy farms.

Research into this intensification has provided ambiguous results for individual EU countries.

Keizer and Emvalomatis (2014) found that TFP components developed consistently at intensive and extensive Dutch farms. By contrast, Alvarez and del Corral (2010) concluded that the intensive technology of Spanish farms was more productive and efficient than extensive technology. In accordance with the Common Agricultural Policy, these authors emphasized the environmental friendliness of intensive dairy production technologies.

Furthermore, the studies have predominantly found that large farms involved in dairy production show quicker growth in total factor productivity than small farms, suggesting that small farms may lag behind large innovative activity. Lansink et al. (2015), also mentioned the role of agricultural policy because the innovative activity of dairy farms is driven significantly by external incentives.

Some authors have also discussed investment subsidies. For example, Špička and Machek (2015) and Žáková Kroupová (2016) found no significant relationship between the growth of TFP and investment subsidies. This suggests that subsidy instruments do not probably achieve the required effectiveness. Operating subsidies, usually analysed according to subsidy-to-income ratio, are commonly considered possessing effects that adversely affect productivity, mainly due to their negative effect on technical efficiency. See, for example, Luik et al. (2011).

Most of the studies examining the total factor productivity of dairy producers were based on a period when milk production was regulated with production quotas. Frick and Sauer (2016) studied the anticipated effects of abandoning milk quotas based on the hypothesis that production quotas adversely affect efficiency and productivity, this effect being reduced by the marketability 
of milk quotas. The study provided empirical evidence that releasing the quota system was linked to reallocating resources towards more productive farms. However, price volatility also affected the reallocation of resources. This rather demotivated less productive agricultural holdings to invest in activity more than productive entities in developing production. It therefore contributed to reallocating resources towards more productive entities. Čechura et al. (2017) can be also mentioned in this context. The authors noted that after milk production quotas were abolished, the shift from EU-13 member states and southern European countries to northern countries was expected, i.e. from less productive to more productive regions.

The aim in this paper is to evaluate the development and main characteristics of Czech milk production productivity and to compare Czech development with the European Union's situation. The paper addresses the following research questions: What is Czech milk production's competitive position in terms of productivity in the EU? What is the main source of milk production productivity growth in the Czech Republic? Is the change in TFP driven by the same component in the Czech Republic and other EU countries? How does Czech milk production differ from the most competitive producers in the EU?

The rest of the paper is organized as follows. The introduction describes the data and methods used. The next section presents the results of the analysis. First, IDF estimates are commented on and the technical efficiency of milk production is discussed. Second, the development of total factor productivity and its components is analysed. In the final section, the characteristics of milk production with the highest TFP change is analysed.

\section{Materials and methods}

Total factor productivity change is analysed according to the approaches of Emvalomatis (2012) and Bauer (1990). Allocation efficiency, which refers to price and marginal cost equality, and a market structure of near perfect competition (Grau and Hockmann, 2016) are assumed.

Total factor productivity change according to the Divisia index is quantified as the sum of three components: scale effect (SEC), technical efficiency change effect (TEC) and technical change effect (TC) $T F P=S E C+T C+T E C$.

These components are derived from the estimate of an input-oriented distance function (Coelli et al., 2003). Input-orientation is preferred over output because of the prevailing existence of milk quotas in the analysed period 2004-2016. Because milk quotas represent a strong restriction on the maximum quantity of milk production, it can be assumed that agricultural producers focus primarily on reducing input to produce almost fixed output (see Kumbhakar et al., 2008). This means that the goal of profit maximization can be achieved by minimizing the cost of producing a fixed (quota) output. According to Skevas et al. (2018), output can be assumed exogenous under this optimization condition.

Bakusc et al. (2012), Latruffe et al. (2011) and Kumbhakar and Tsionas (2008) have also estimated the input-oriented distance function for specialized milk production. Morrison Paul et al. (2004) also generally recommended the input-oriented function for analysing agricultural production, arguing that agricultural producers have more control over input than output over a short period of time.

Using the homogeneity property of IDF, the following random parameter stochastic translog IDF with $M$ outputs $(Y), J$ inputs $(X)$ and time $(T)$ can be estimated:

$$
\begin{aligned}
-\ln X_{1 i t} & =A_{i}+v_{i t}-u_{i t}, \\
\text { where } A_{i} & =\alpha_{0, i}+\sum_{m=1}^{2} \beta_{m, i} \ln Y_{m, i t}+ \\
& +\frac{1}{2} \sum_{m=1}^{2} \sum_{n=1}^{2} \beta_{m n} \ln Y_{m, i t} \ln Y_{n i, t}+ \\
& +\sum_{m=1}^{2} \sum_{j=2}^{5} \delta_{m j} \ln Y_{m, i t} \ln \tilde{X}_{j, i t}+ \\
& +\sum_{j=2}^{5} \beta_{j, i} \ln \tilde{X}_{j, i t}+ \\
& +\frac{1}{2} \sum_{j=2}^{5} \sum_{k=2}^{5} \beta_{j k} \ln \tilde{X}_{j, i t} \ln \tilde{X}_{k, i t}+ \\
& +\alpha_{t, i} T+\frac{1}{2} \alpha_{t t} T^{2}+ \\
& +\sum_{m=1}^{2} \alpha_{m t} \ln Y_{m, i t} T+ \\
& +\sum_{j=2}^{5} \alpha_{j t} \ln \tilde{X}_{j, i t} T
\end{aligned}
$$

where $v_{i t} \sim N\left(0, \sigma_{v}^{2}\right)$ is the stochastic error term, $u_{i t}=\left|U_{i t}\right|, U_{i t} \sim N\left(\mu_{i}, \sigma_{u}^{2}\right)$ is the time-varying inefficiency, and $\ln \tilde{X}_{j, i t}=\ln X_{j, i t}-\ln X_{1, i t}, \alpha, \beta, \delta$ are the estimated parameters. The symmetry restrictions imply that $\beta_{j k}=\beta_{k j}$ and $\beta_{m n}=\beta_{n m}$.

Furthermore, normalization ensures the exogeneity of input (Sipiläinen et al., 2014) and consistency of estimation (Kumbhakar, 2011). All variables were also normalised as logarithms at their sample mean, which made it possible to interpret the estimated first-order parameters as elasticities at the sample mean. The random parameter model was fitted according to the maximum simulated 
likelihood with a Halton sequence assuming a normal distribution of random parameters in the SW NLOGIT 5.0.

The technical change component can be computed from IDF as in Equation (2):

$$
\begin{aligned}
T C & =-\frac{\partial \ln D_{i t}^{I}}{\partial T}=-\left(\alpha_{t}+\alpha_{t t} T\right. \\
& \left.+\sum_{m=1}^{M} \alpha_{m t} \ln Y_{m i, t}+\sum_{j=2}^{J} \alpha_{j t} \ln \tilde{X}_{j i, t}\right) .
\end{aligned}
$$

According to Lansink et al. (2000), technical change can be further decomposed into a Hicks neutral: $T C_{n}=-\left(\alpha_{t}+\alpha_{t t} T\right)$ and factor-biased technical change $T C_{b}=-\left(\sum_{m=1}^{M} \alpha_{m t} \ln Y_{m i, t}+\sum_{j=2}^{J} \alpha_{j t} \ln \tilde{X}_{j i, t}\right)$, which indicates a change in factor productivity allowing certain inputs to be saved.

The scale effect can be quantified as:

$S E C=\dot{Y}_{C}\left(1+\varepsilon^{C Q}\right)$,

where $\dot{Y}_{C}=\sum_{m} \frac{\frac{\partial \ln D_{i t}^{I}}{\partial \ln Y_{m i, t}}}{\sum m \frac{\partial \ln D_{i t}^{I}}{\partial \ln Y_{m i, t}}} \frac{\left(Y_{m, t}-Y_{m, t-1}\right)}{0.5\left(Y_{m . t}+Y_{m, t-1}\right)}$

is the weighted aggregate rate of change in output and $\varepsilon^{C Q}=\sum_{m} \frac{\partial \ln D^{I}(y, x, t)}{\partial \ln y_{m}}$ is the sum of elasticities of IDF with respect to output (see Kumbhakar and Lozano-Vivas, 2005).

As noted by Sipiläinen et al. (2014), the use of averages for the consecutive periods $t-1$ and $t$ ensures that the analysis is consistent over time for 'static' variables.

Finally, the technical efficiency change was computed using Equation (4):

$$
T E C_{i, t}=\frac{\widehat{T E}_{i, t}-\widehat{T E}_{i, t-1}}{0.5\left(\widehat{T E}_{i, t}+\widehat{T E}_{i, t-1}\right)}
$$

where the technical efficiency was estimated according to Jondrow et al. (1982).

Calculation of the components was conducted using software R, version 3.5.0. The quantified components were further evaluated in relation to the specific characteristics of milk production in the FADN regions. Specialization, milk yield, farm size, proportion of paid labour, proportion of rented agricultural land, proportion of feed from own production, labour intensity, indebtedness, localisation in Less Favoured Areas (LFA) and subsidies were especially studied. The differences in these characteristics between Czech milk production and milk production in the most competitive countries were tested using the Kruskal-Wallis test.
The analysis used unbalanced panel data set of TF14-45 specialist milk drawn from the FADN database. The data covers the period 2004-2016 and 27 European Union member states. No data was available for specialized milk production in Cyprus and Greece. The data set consists of 1,343 observations of FADN regions. Although regional data represent the lowest level of aggregation freely available in the FADN database, it introduced several limitations into the analysis, including the unfeasibility of evaluating the variability of input and output in the production process at the farm level (i.e., in FADN regions). The estimated frontier according to regional data may differ from the true frontier estimated from farm data. The low quantity of regional data also made it unfeasible to model the meta-frontier. Concerning the use of FADN data, the sample might not necessarily be representative of the dairy farm sector in each country since the smallest farms are not covered by FADN data. Furthermore, the FADN sample may change every year, with some farms entering the sample and others leaving (the reasons may be termination of activities, shortcomings in accounting, etc.). However, it can be assumed that the FADN sector data show the same tendencies as specific sectors in the FADN region. The limitations related to applying aggregated FADN data are also mentioned by Madau et al. (2017), who analysed the technical efficiency and productivity of 22 European countries in 2004-2012 based on FADN country data.

In order to estimate the IDF in this study, the following outputs and inputs were used: milk production (Y1) in kilos (SE125N), other production (Y2) in EUR, which is determined from the sum of crop production (SE135), other animal production (SE206 minus the production of milk in EUR (SE216)) and other production (SE256), the cost of feed for grazing livestock (X1) in EUR (SE310), labour (X2) measured in working hours (SE011), the total utilized agricultural area (X3) in hectares (SE025), capital (X4) in EUR measured as depreciation (SE360), and the costs of other materials (X5) in EUR (total intermediate consumption (SE275) minus feed for grazing livestock (SE310)). Outputs and inputs (except for milk production, labour and land), are deflated by price indices (individual output and input indices $(2010=100)$ - source is the EUROSTAT database $)$.

\section{Results and discussion}

Table 1 shows the estimated parameters of the inputdistance function. Almost all of the parameters 
are significant, even at the $1 \%$ significance level. The estimated model also satisfied the properties of an input distance function, namely symmetry, monotonicity, linear homogeneity and concavity in inputs and quasi-concavity in outputs. Since all variables were normalised as logarithms at their sample mean, the first-order parameters can be interpreted as the elasticity of the IDF with respect to output on the sample mean and as the proportion of input in the total input. Table 1 shows that the input proportion of capital (X4) was the lowest (0.06), the input proportion of labour (X2) was the highest $(0.37)$ i.e. the proportion of capital in the total input was only $6 \%$, though the proportion of labour was about $37 \%$. This reflects capital market imperfections, especially at the beginning of the analysed time period and in the group of countries accessing to the EU in/after 2004 (EU-13). However, the analysed time period saw an increase in the proportion of capital in total input and a reduction in the proportion of land (X3) and other materials (X5, except for feeds). This may indicate the modernization of production towards more material-efficient and less land-bound technologies. Sipiläinen et al. (2014) also found a high proportion of labour and low proportion of capital in total dairy farm inputs according to the data from Finnish and Norwegian milk production.

The elasticity of milk (Y1) that corresponds to the negative of the cost elasticity of the particular output (see Irz and Thirtle, 2004), was about (-0.51). The negative inversion of the sum of partial elasticities of outputs, which corresponds to economies of scale, was statistically significantly different from the one at the $1 \%$ significance level according to a t-test $(\mathrm{t}$-value $=65.240)$ and averages 1.36. That is, milk production can be characterized by the existence of increasing returns to scale. In only $10 \%$ of cases (especially Romania, Hungary, Finland, Estonia, Spain), the estimated value of economies of scale was less than one, which corresponds to decreasing returns to scale. Čechura et al. (2017) also identified prevailing increasing returns to scale in European dairy farms

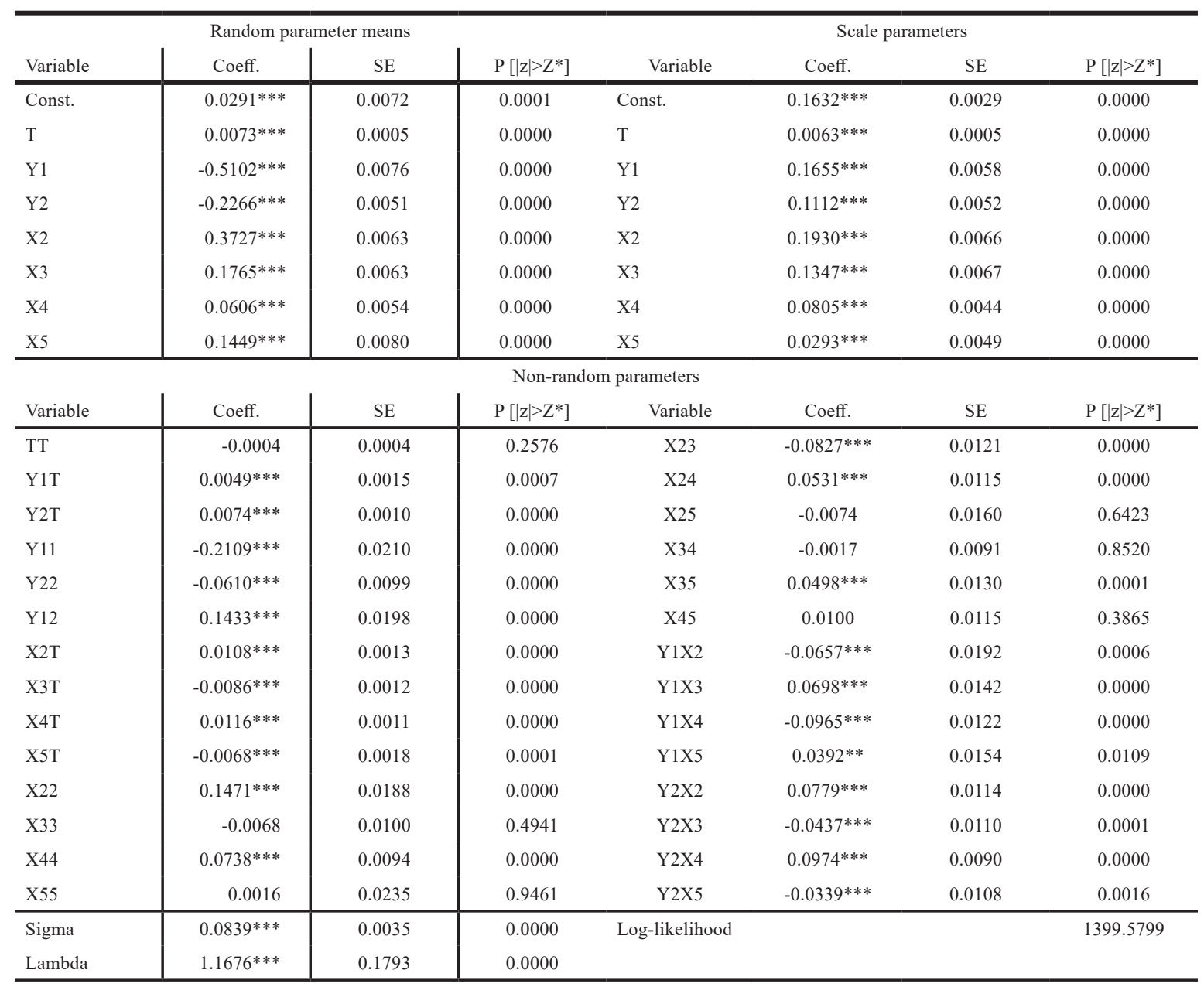

Note: $* * *, * *, *$ denote significance at the $1 \%, 5 \%$, and $10 \%$ levels, respectively

Source: Author's calculations

Table 1: Estimated parameters. 
in the farm-level data from 2004-2011.

According to Rasmussen (2011), assuming homothetic production technology, economies of scale can be interpreted in the same manner as economies of size. The estimated value of economies of scale therefore suggests that the size of the dairy specialized farms of FADN regions is below the technically optimal level. Moving to a technically optimal size would bring cost savings to EU dairy producers. It can be stated that Czech milk production is close to the technically optimal size. The value of returns to scale was 1.03 for the Czech Republic.

The parameter lambda is also significant at the $1 \%$ significance level and greater than one. The variation in technical inefficiency is more pronounced than the variation in the stochastic error. This indicates that most of the deviation from the frontier of the input requirement set was due to technical inefficiencies rather than random shocks. The average technical efficiency of specialized milk production was $94.28 \%$, with a standard deviation of $2.64 \%$. The minimum value of technical efficiency was $79.23 \%$. However, for only $5 \%$ of the observations, a technical efficiency less than $89.24 \%$ was found, and only $25 \%$ of the observations had a technical efficiency score of less than $93.56 \%$. Conversely, $25 \%$ of the most successful regions show the technical efficiency of dairy producers as greater than $95.80 \%$, with a maximum of $98.74 \%$. This suggests that European milk production highly exploited its production possibilities in 2004-2016.

In the Czech Republic, the average value of technical efficiency was $94.01 \%$ over the analysed time period. Compared to other member states, this figure is above the EU-13 average (93.71\%) shown in Figure 1. Poland is the only country that achieves a higher value in the Visegrad group.

The average technical efficiency of the EU-13 states was below the EU-15 average (94.45\%). The difference in the average technical efficiency scores of the EU-13 and EU-15 group was statistically significant at $\alpha=0.05$ (t-value $=-3.764)$.

The development of technical efficiency is shown in the second graph (Figure 2). The graph shows that development in the EU-13 was characterized by more significant fluctuations than in the EU-15. The comparison of the average technical efficiency between 2016 and 2004 shows a slight decrease in the average technical efficiency of EU milk production, driven mainly by the decrease in technical efficiency in the EU-13 countries. It is clear that changes in technical efficiency do not have the same direction in the old and new

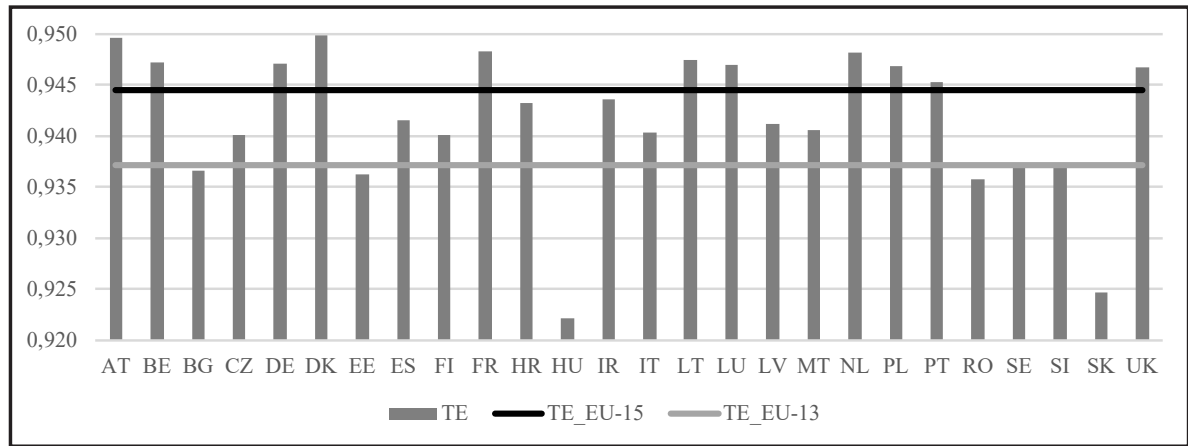

Source: Author's calculations

Figure 1: Technical efficiency (TE): country-specific average values.

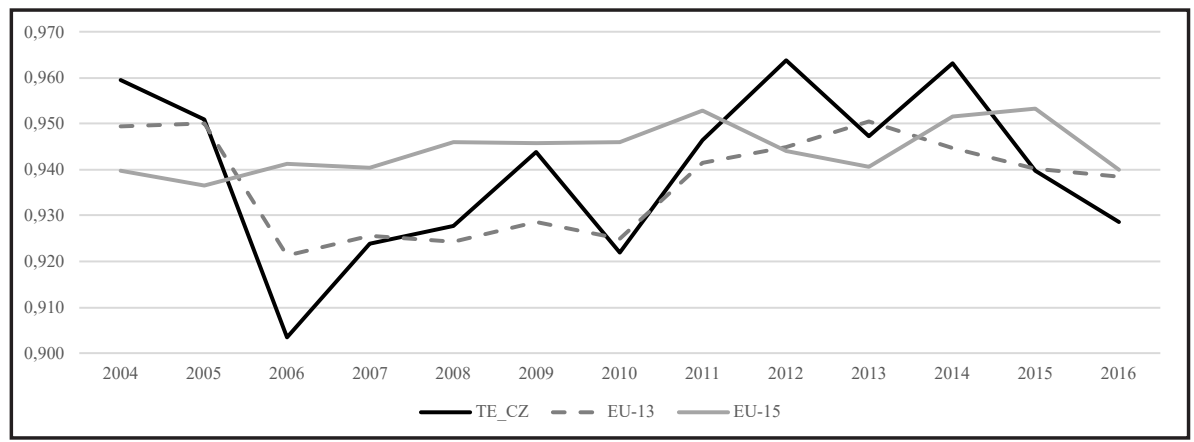

Source: Author's calculations

Figure 2: Technical efficiency development. 
member states. Most of the changes suggest that development in the EU-15 countries prefigures development in the EU-13.

In the Czech Republic, 2006, 2010 and 2015 saw significant declines. The 2006 decline can be considered the result of reform in the Common Agricultural Policy and dairy market regulation (especially the decline of intervention prices). The decline in 2010 was a result of economic crisis. The dairy crisis in 2015 was caused by a surplus of milk on world markets, not only because milk quotas were abolished but also because demand from China reduced and because of a Russian embargo. Only Slovakia (standard deviation in technical efficiency: 5.13\%) from the Visegrad Group countries showed significantly higher fluctuations than the Czech Republic (standard deviation: $1.81 \%$ ), but only in the first half of the analysed period. Since 2009, unlike Czech milk production, a steady increase in the technical efficiency of Slovak dairy farms can be observed. This indicates the high sensitivity of Czech milk production to crisis periods and the limited ability of Czech dairy farms to manage shocks affecting short-term production.
The development of technical efficiency influences the total factor productivity change. The third graph (Figure 3) charts the total factor productivity index of Czech milk production. It is clear that in the crisis periods described above, the negative effect of technical efficiency (falling-behind of dairy producers) caused a fall in total factor productivity, except for 2015, when a positive change in TFP was maintained by a strong scale effect (optimizing the scale of operations). The scale effect and the technical efficiency change effect can be considered the main components of TFP changes in Czech milk production in 2004-2016. The technical change component (implementing new technologies) influenced TFP particularly at the beginning of the analysed period. This demonstrates the positive impact of investments supported by pre-accession programmes as well as the absence of innovation at the end of the analysed period.

A comparison with developments on world markets suggests that the effect of technical efficiency responds more flexibly to the deterioration of production, sales or economic conditions than the scale effect, where a time lag is apparent.

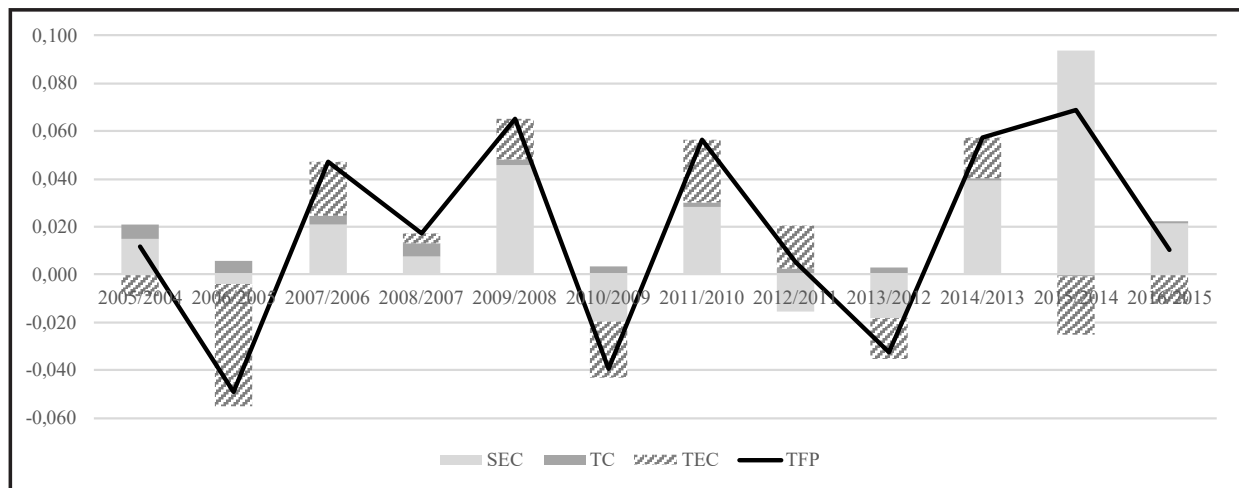

Note: TFP is the total factor productivity change, SEC is the scale effect, TC is the technical change, TEC is the effect of technical efficiency change.

Source: Author's calculations

Figure 3: Total factor productivity index: Czech milk production.

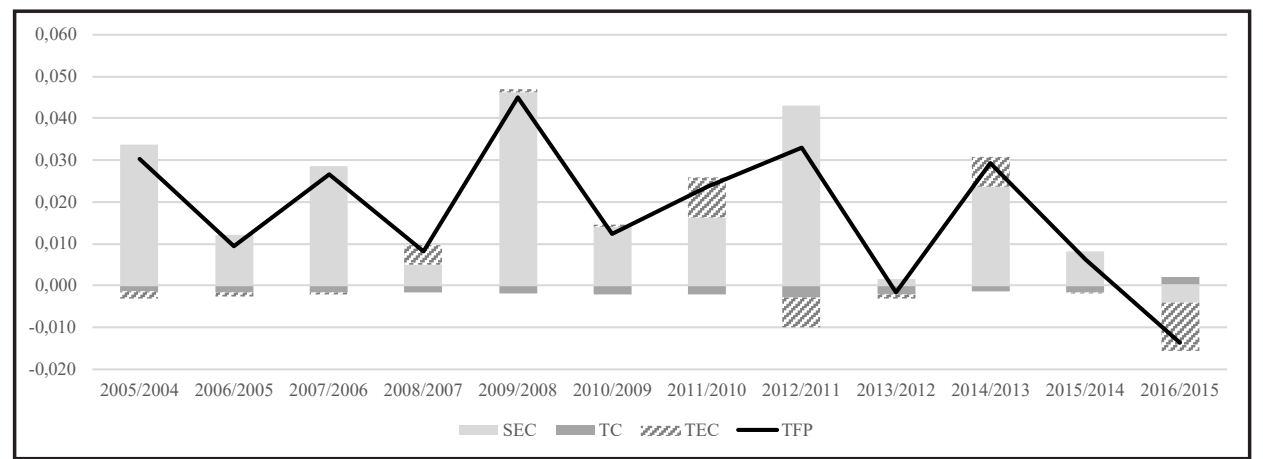

Note: TFP is the total factor productivity change, SEC is the scale effect, TC is the technical change, TEC is the effect of technical efficiency change.

Source: Author's calculations

Figure 4: Total factor productivity index: EU milk production. 
The fourth graph (Figure 4.), which describes the development of TFP and its components in EU milk production, indicates that the total factor productivity of European milk production was influenced more by the scale effect than Czech production. The scale effect was therefore more pronounced in the EU-15 member states. However, even in the EU-13 group, it was mainly structural changes that contributed to productivity growth (Table 2).

Table 2 shows that technological decline even decelerated the growth in TFP in the EU13 countries in 2004-2016. While the EU-15 has seen technological progress since 2014, the impact of technological decline strengthened in EU-13 countries at the end of the analysis period, i.e. dairy producers in EU-13 countries lagged behind in innovative activities.

Overall, the TFP components resulted in a $1.8 \%$ year-on-year increase in total factor productivity in the Czech Republic (Table 2). Czech milk production was characterized by a $1.8 \%$ year-onyear increase in the output-input ratio on average in the period 2004-2016. The TFP of dairy producers grew faster in the Czech Republic than in the EU-13 group or other members of the Visegrad group (Table 3 ).

Table 2 also shows that specialized milk production in EU-15 was characterized by higher TFP growth than milk production in EU-13. Čechura et al. (2017) presented similar findings based on farm data. These authors concluded that the positive economic effects expected from economic integration and the convergence of EU regions in terms of dairy productivity had not yet been achieved.

The difference in TFP change between the EU15 and EU-13 groups is statistically significant at $\alpha=0.05$ (t-value $=3.182$ ). Quicker growth in the EU-15 was driven by a more significant scale effect and the contribution of technical change and technical efficiency. In the EU-13, both technical change and technical efficiency change (falling-behind) on average weakened the positive scale effect.

In accordance with the previous results, the dominant influence of the scale effect was also apparent from the perspective of member states (Table 3). The exceptions were Croatia, Finland, Italy, Malta, Portugal, Austria and Romania, where total factor productivity development was primarily determined by the effect of technical change. However, in most of these countries, the impact of technical change on TFP change was negative. Technical efficiency compared to other components had a minor effect on TFP change. The stronger impact of technical efficiency change compared to technical change was apparent only in Luxembourg, Hungary, Germany and Slovakia. On average, the effect of technical efficiency had almost the same absolute value as the effect of technical change in the Czech Republic and Lithuania.

The effect of technical change was mainly driven by neutral technical change, with the exception of Denmark, France, Italy, Luxembourg, Malta, Portugal, Austria, Romania, Slovakia, Slovenia and Spain. In these countries, factor-biased technical change was more significant on average in the analysed period. Almost the same effect of these components of technical change can be seen in the UK and Hungary, where these effects eliminated each other. A negative factor-biased technical change was found in the Czech Republic, and this effect reduced the positive effect of neutral technical change.

\begin{tabular}{lcccccc}
\hline & \multicolumn{2}{c}{ CZ } & \multicolumn{2}{c}{ EU-15 } & \multicolumn{2}{c}{ EU-13 } \\
& Mean & St. dev. & Mean & St. dev. & Mean & St. dev. \\
\hline TFP & 0.0182 & 0.0418 & 0.0213 & 0.0632 & 0.0030 & 0.0832 \\
SEC & 0.0179 & 0.0324 & 0.0210 & 0.0631 & 0.0110 & 0.0721 \\
TC & 0.0030 & 0.0021 & 0.0001 & 0.0103 & -0.0074 & 0.0089 \\
TEC & -0.0027 & 0.0240 & 0.0001 & 0.0249 & -0.0005 & 0.0405 \\
\hline
\end{tabular}

Note: TFP is the total factor productivity change, SEC is the scale effect, TC is the technical change, TEC is the effect of technical efficiency change.

Source: Author's calculations.

Table 2: Comparison of TFP change in the Czech Republic, EU-15 and EU-13. 


\begin{tabular}{|c|c|c|c|c|}
\hline Country & TFP & SEC & $\mathrm{TC}$ & TEC \\
\hline Austria & 0.0010 & 0.0139 & -0.0110 & -0.0019 \\
\hline Belgium & 0.0316 & 0.0382 & -0.0044 & -0.0022 \\
\hline Bulgaria & -0.0063 & 0.0056 & -0.0080 & -0.0039 \\
\hline Croatia & -0.0244 & 0.0063 & -0.0221 & -0.0086 \\
\hline Czech Republic & 0.0182 & 0.0179 & 0.0030 & -0.0027 \\
\hline Denmark & 0.0480 & 0.0473 & 0.0021 & -0.0015 \\
\hline Estonia & 0.0345 & 0.0167 & 0.0109 & 0.0068 \\
\hline Finland & 0.0240 & 0.0091 & 0.0114 & 0.0035 \\
\hline France & 0.0276 & 0.0257 & 0.0021 & -0.0002 \\
\hline Germany & 0.0242 & 0.0253 & 0.0005 & -0.0015 \\
\hline Hungary & 0.0116 & 0.0119 & 0.0006 & -0.0010 \\
\hline Ireland & 0.0351 & 0.0368 & -0.0045 & 0.0028 \\
\hline Italy & 0.0010 & 0.0134 & -0.0120 & -0.0005 \\
\hline Latvia & 0.0182 & 0.0277 & -0.0096 & 0.0000 \\
\hline Lithuania & 0.0094 & 0.0140 & -0.0026 & -0.0020 \\
\hline Luxembourg & 0.0405 & 0.0404 & -0.0011 & 0.0012 \\
\hline Malta & -0.0162 & 0.0081 & -0.0258 & 0.0015 \\
\hline Netherlands & 0.0229 & 0.0298 & -0.0042 & -0.0026 \\
\hline Poland & 0.0064 & 0.0156 & -0.0067 & -0.0025 \\
\hline Portugal & 0.0200 & 0.0020 & 0.0100 & 0.0079 \\
\hline Romania & -0.0087 & 0.0006 & -0.0116 & 0.0022 \\
\hline Slovakia & 0.0152 & 0.0142 & -0.0006 & 0.0016 \\
\hline Slovenia & 0.0110 & 0.0272 & -0.0179 & 0.0018 \\
\hline Spain & 0.0327 & 0.0268 & 0.0061 & -0.0002 \\
\hline Sweden & 0.0295 & 0.0116 & 0.0108 & 0.0071 \\
\hline United Kingdom & 0.0220 & 0.0149 & 0.0074 & -0.0003 \\
\hline
\end{tabular}

Note: TFP is the total factor productivity change, SEC is the scale effect, TC is the technical change, TEC is the effect

of technical efficiency change.

Source: Author's calculations.

Table 3: Total factor productivity change in EU member states.

In detail, it can be concluded that the main source of dairy productivity growth in most regions of the EU was the increasing size of specialized dairy farms, accompanied by structural changes associated with the concentration of production in the most competitive regions. The changes were amplified by the release and subsequent abolition of milk quotas, which prevented the increase in output and reallocation of inputs among producers and thereby produced welfare losses (see Kumbhakar et al., 2008 and Frick and Sauer, 2016).

Productivity gains due to the elimination of underutilized resources were apparent in Estonia, Finland, Ireland, Luxembourg, Malta, Portugal, Romania, Slovakia, Slovenia and Sweden. The technical change, indicating innovations that save input involved in producing a given amount of output, was evident in the Czech Republic, Denmark, Estonia, Finland, France, Hungary, Germany, Portugal, Spain, Sweden and the United
Kingdom. The source of the technological shift probably was the improvement of the genetic potential of farmed dairy cows or technological innovations (Lansink et al., 2015).

The positive effect of the technical change was mainly due to neutral technical changes in the Czech Republic, Estonia, Finland and Germany. In Denmark, France, Portugal and Spain, factor-biased technical change, i.e. the influence of technology on the change in the use of production factors, was more significant. However, in the Czech Republic, Denmark, France, Hungary, Germany, Spain and the United Kingdom, a similar situation to the work of Emvalomatis (2012) in cases of German dairy farms in 1995-2004 can be observed: the positive technical change was accompanied by a negative effect from technical efficiency. The contradictory tendencies of technical efficiency and technological progress have also been highlighted by Dakpo et al. (2019), who analysed French dairy farms. This may indicate that dairy producers in these countries are facing differences in time when new technology is introduced and the knowledge on how to fully make use of it is acquired. Practical examples are shortcomings in the setup of milking equipment, which may cause decreased milk yields.

As in the Czech Republic, TFP growth in most EU countries over the analysed period can be seen. TFP decline only occurred in Croatia, Italy, Malta and Romania (Table 3). Furthermore, countries with significantly above-average productivity changes (i.e., $25 \%$ of country-aggregated observations with the highest average productivity change), namely Denmark, Luxembourg, Ireland, Estonia, Belgium, Spain and Sweden, were found in the analysed sample. These countries have strengthened their competitive position. By contrast, Austria, Poland, Lithuania and Slovenia showed significantly below-average growth, indicating a weakening of the competitiveness of this group of countries.

Milk production with the highest productivity growth in 2004-2016 was characterized by a high level of specialization. The proportion of milk production in total output was $75 \%$ on average. This was significantly higher than in Czech milk production (Table 4). Compared to the Czech Republic, the group of countries with significantly above-average TFP change is represented by dairy specialized producers with high milk yields in the FADN database. 


\begin{tabular}{l|ccc}
\hline & $\begin{array}{c}\text { Czech milk } \\
\text { production }\end{array}$ & $\begin{array}{c}\text { Above-average } \\
\text { TFP group }\end{array}$ & Sig. \\
\hline $\begin{array}{l}\text { Proportion of milk on total } \\
\text { output [\%] }\end{array}$ & 49.70 & 75.01 & $* * *$ \\
Milk yield [kilos/LU] & 6403.71 & 7262.10 & $* *$ \\
Agriculture area [hectares] & 265.29 & 64.57 & $* * *$ \\
Dairy herd [LU] & 93.10 & 65.21 & $* * *$ \\
Economic size [ESU] & 304.82 & 204.76 & $* * *$ \\
Proportion of paid labour [\%] & 82.98 & 15.58 & $* * *$ \\
Proportion of rented land [\%] & 85.42 & 55.60 & $* * *$ \\
Proportion of own feed [\%] & 60.26 & 24.08 & $* * *$ \\
Long-term indebtedness & 19.49 & 16.94 & $* * *$ \\
Labour intensity [hours/LU] & 228.20 & 72.96 & $* * *$ \\
$\begin{array}{l}\text { Proportion of total subsidies } \\
\text { in production [\%] }\end{array}$ & 30.35 & 16.66 & $* * *$ \\
$\begin{array}{l}\text { Proportion of investment } \\
\text { subsidies in total subsidies }\end{array}$ & 4.21 & 5.99 & $* * *$ \\
[\%] & & & \\
$\begin{array}{l}\text { Decoupled payments } \\
\text { [Eur/hectares] }\end{array}$ & 151.50 & 322.35 & $* * *$ \\
Livestock subsidies [Eur/LU] & 42.94 & 53.02 & \\
$\begin{array}{l}\text { LFA subsidies [Eur/hectares] } \\
\text { Farm net value added }\end{array}$ & 57.00 & 40.24 & $* * 19$ \\
[Eur/AWU] & 6.82 & & \\
\hline
\end{tabular}

Note: The above-average group represents Denmark, Luxembourg, Ireland, Estonia, Belgium, Spain and Sweden $* * *, * *$ denote significance at the $1 \%$ and $5 \%$ levels in the Kruskal-Wallis test, respectively.

Source: Author's calculations

Table 4: Characteristics of milk production in the Czech Republic and in the group with above-average TFP growth.

Czech dairy producers made significantly greater use of agricultural area than the group of most competitive countries. This was associated with a higher proportion of the Czech Republic's own feed production $(60 \%)$. Due to the higher localization of production in LFA in the Czech Republic, a lower quality of home-grown feed can be considered. Other differences can be seen in the dependence on external inputs, namely labour and land. The high dependence of Czech milk production on external labour and land may endanger the economic situation of producers. Rising labour and land prices may lead to a loss of profitability. External workers are more susceptible to fluctuations than family workers. The fluctuation of labour may also involve the risk of losing specialized workers with appropriate skills. Table 4 suggests that there were significantly more working hours per livestock unit in the Czech Republic, which also indicates a lack of mechanization and automation in milk production, which may relate to the aforementioned decline in impact of technological change at the end of the analysis period. Investment subsidies also probably did not contribute sufficiently to companies' innovation activities leading to technological progress, as the proportion in total subsidies between the Czech Republic and the above-average group was similar. Žáková Kroupová (2016) also did not find a significant relationship between investment subsidies and technical change according to the farm data from 2004-2011 of Czech dairy producers.

The economic situation of Czech, and in general, European dairy producers has been significantly influenced by subsidy payments. Table 4 shows that for each euro of production created, Czech dairy producers received 0.3 EUR of subsidies. This is significantly more than the most competitive group, where the value of decoupled payments per hectare and the value of livestock subsidies per livestock unit was higher than in the Czech Republic. Lower agricultural producer milk prices and high average production costs, together with lower subsidy payments, resulted in low profitability in specialized Czech milk production.

\section{Conclusion}

The aim in this paper was to evaluate the development of Czech milk production productivity and its main characteristics and to compare with EU milk production productivity. The analysis examined the inputoriented distance function and the total factor productivity and its partial components, i.e. scale effect, technical efficiency change effect and technical change effect, in the Czech, EU-15 and EU-13 milk sectors using FADN data from the period 2004-2016. The following research questions were addressed: What is Czech milk production's competitive position in terms of productivity in the EU? What is the main source of milk production productivity growth in the Czech Republic? Is the change in TFP driven by the same component in the Czech Republic and other EU countries? How does Czech milk production differ from the most competitive producers in the EU? These questions were answered consecutively in the Results and discussion section.

The estimated IDF function revealed the lowest proportion of capital in the total input (only $6 \%$ ), reflecting capital imperfections, especially at the beginning of the analysed period, in the group of EU-13 countries. However, the modernization of production towards more material-efficient and less land-bound technologies was also detected. The IDF also confirmed prevailing increasing returns to scale in the EU milk sector. 
Examination of technical efficiency showed an above-average position of the Czech Republic (94.01\%) compared to the EU-13 average (93.71\%). However, the TE level average in the EU-13 was lower than the TE level average in the EU-15 (94.45\%). Furthermore, the development of the average technical efficiency of EU-13 countries was characterized by more significant fluctuations than the average technical efficiency of EU-15 countries.

The development of technical efficiency influences the total factor productivity change. Analysis of the total factor productivity showed that the scale effect and technical efficiency change effect can be considered the main components of TFP changes in Czech milk production. Further examination discovered that the effect of technical efficiency responded more flexibly to the deterioration of production, sales, or economic conditions than the scale effect, where a time lag was apparent. On the other hand, the scale effect was more significant in other EU countries, especially the EU-15, compared to the Czech milk sector.

Czech milk production can be also characterized by a $1.8 \%$ year-on-year increase in the outputinput ratio on average in the period 2004-2016, which indicates a quicker increase compared to EU-13 countries. On the other hand, milk production in the EU-15 countries was characterized by higher TFP growth than milk production in the EU-13. Quicker growth in the EU-15 was driven by a more significant scale effect and the contribution of technical change and technical efficiency.

In conclusion, the relationship between milk production growth and level of specialization should be also considered. In the Czech Republic, several factors influencing milk production productivity compared to the most competitive EU producers were seen. For example, higher agricultural area use, higher proportion of own feed production, lower feed quality, dependence on external input as labour and land or level of subsidies.

\section{Acknowledgements}

The results are the part of the solution of project No. QK1920398 „Duality in Czech Agriculture: Advantage or Disadvantage for New Generation Agriculture?", supported by the Ministry of Agriculture of the Czech Republic, program ZEMĚ.

\section{Corresponding authors}

doc. Ing. Zdeňka Žáková Kroupová, Ph.D.

Department of Economics, Faculty of Economics and Management

Czech University of Life Sciences Prague, Kamycka 129, Prague - Suchdol, 165 00, Czech Republic

Phone: +420 224382 303,E-mail: kroupovaz@pef.czu.cz

\section{References}

[1] Alvarez, A., del Corral, J. (2010) "Identifying different technologies using a latent class model: extensive versus intensive dairy farms“, European Review of Agricultural Economics, Vol. 37, No. 2, pp. 231-250. ISSN 0165-1587. DOI 10.1093/erae/jbq015.

[2] Bakucs, L. Z., Fertö, I., Fagarasi, J. and Tóth, J. (2012) "Farm organisation and efficiency in Hungarian dairy farms", Milchwissenschaft, Vol. 67, No. 2, pp. 147-150. ISSN 0026-3788.

[3] Barnes, A. (2008) "Technical Efficiency Estimates of Scottish Agriculture: A Note“, Journal of Agricultural Economics, Vol. 59, No. 2, pp. 370-376. ISSN 1477-9552. DOI 10.1111/j.1477-9552.2008.00156.x.

[4] Bauer, P. W. (1990) "Decomposing TFP growth in the presence of cost inefficiency, nonconstant returns to scale, and technological progress", Journal of Productivity Analysis, Vol. 1, No. 4, pp. 287-299. ISSN 1573-0441. DOI 10.1007/BF00160047.

[5] Bokusheva, B., Čechura, L. (2017) “Evaluating dynamics, sources and drivers of productivity growth at the farm level", OECD Food, Agriculture and Fisheries Papers, No. 106, OECD Publishing, Paris.

[6] Coelli, T., Singh, S. and Fleming, E. (2003) "An input distance function approach to the measurement of technical and allocative efficiency: with application to Indian dairy processing plants". [Online]. Available: https://editorialexpress.com/cgibin/conference/download. cgi?db_name=esam2003\&paper_id=105 [Accessed: 15 March 2015]. 
[7] Čechura, L., Grau, A., Hockmann, H., Levkovych, I. and Kroupova, Z. (2017) "Catching up or falling behind in Eastern European agriculture - the case of milk production", Journal of Agricultural Economics, Vol. 68, No. 1, pp. 206-227. ISSN 1477-9552. DOI 10.1111/1477-9552.12193.

[8] Dakpo, K. H., Desjeux, Y., Jeanneaux, P. and Latruffe, L. (2019) "Productivity, technical efficiency and technological change in French agriculture during 2002-2015: a Färe-Primont index decomposition using group frontiers and meta-frontier", Applied Economics, Vol. 51, No. 11, pp. 1166-1182. ISSN 0003-6846. DOI 10.1080/00036846.2018.1524982.

[9] Emvalomatis, G. (2012) "Productivity Growth in German Dairy Farming Using a Flexible Modelling Approach", Journal of Agricultural Economics, Vol. 63, No. 1, pp. 83-101. ISSN 1477-9552. DOI 10.1111/j.1477-9552.2011.00312.x.

[10] Frick, F. and Sauer, J. (2016) "Deregulation and Productivity: Empirical Evidence on Dairy Production", Paper presented on the annual meeting of Agriculture \& Applied Economics Association, $31^{\text {th }}$ July-2 $2^{\text {nd }}$ August 2016, Boston, USA.

[11] Grau, A. and Hockmann, H. (2016) "A new approach to identify market power along agri-food supply chains - the German dairy supply chain", Paper presented on the annual meeting of Agriculture \& Applied Economics Association, $31^{\text {th }}$ July- $2^{\text {nd }}$ August 2016, Boston, USA.

[12] Irz, X. and Jansik, C. (2015) "Competitiveness of dairy farms in northern Europe: A crosscountry analysis“, Agricultural and Food Science, Vol. 24, pp. 206-2018. ISSN 1795-1895. DOI 10.23986/afsci.50881.

[13] Irz, X. and Thirtle, C. (2004) "Dual Technological Development in Botswana Agriculture: A Stochastic Input Distance Function Approach“, Journal of Agricultural Economics, Vol. 55, No. 3, pp. 455-478. ISSN 1477-9552. DOI 10.1111/j.1477-9552.2004.tb00110.x.

[14] Jondrow, J., Knox Lovell, C. A., Materov, I. S. and Schmidt, P. (1982) "On the Estimation of Technical Inefficiency in the Stochastic Frontier Production Function Model", Journal of Econometrics, Vol. 19, No. 2/3, pp. 233-238. ISSN 0304-4076. DOI 10.1016/0304-4076(82)90004-5.

[15] Keizer, T. H. and Emvalomatis, G. (2014) "Differences in TFP growth among groups of dairy farms in the Netherlands“, NJAS-Wageningen Journal of Life Science, Vol. 70-71, pp. 33-38. ISSN 1573-5214. DOI 10.1016/j.njas.2014.03.001.

[16] Kumbhakar, S. C. (2011) "Estimation of production technology when the objective is to maximize return to the outlay", European Journal of Operational Research, Vol. 208, pp. 170-176. ISSN 0377-2217. DOI 10.1016/j.ejor.2010.09.015.

[17] Kumbhakar, S. C. and Tsionas, E. G. (2009) "Stochastic error specification in primal and dual production systems", Journal of Applied Econometrics, Vol. 26, pp. 270-297. ISSN 1099-1255. DOI 10.1002/jae.1100.

[18] Kumbhakar, S. C. and Tsionas, E. G. (2008) "Estimation of input-oriented technical efficiency using a nonhomogeneous stochastic production frontier mode", Agricultural Economics, Vol. 38, pp. 99-108. ISSN 1574-0862. DOI 10.1111/j.1574-0862.2007.00285.x.

[19] Kumbahakar, S. C., Lien, G., Flaten, O. and Tveteras, R. (2008) "Impacts of Norwegian Milk Quotas on Output Growth: A Modified Distance Function Approach", Journal of Agricultural Economics, Vol. 59, No. 2, pp. 350-369. ISSN 1477-9552. DOI 10.1111/j.1477-9552.2008.00154.x.

[20] Kumbhakar, S. C. and Lozano-Vivas, A. (2005) "Deregulation and Productivity: The Case of Spanish Banks", Journal of Regulatory Economics, Vol. 27, No. 3, pp. 331-351. ISSN 0922-680X. DOI 10.1007/s11149-005-6627-2.

[21] Lansink, A. O., Stefanou, S. and Serra, T. (2015) "Primal and dual dynamic Luenberger productivity indicators", European Journal of Operational Research, Vol. 241, pp. 555-563. ISSN 0377-2217. DOI 10.1016/j.ejor.2014.09.027. 
[22] Lansink, A. O., Silva, E. and Stefanou, S. (2000) "Decomposing productivity growth allowing efficiency gains and price-induced technical progress", European Review of Agricultural Economics, Vol. 27, No. 4, pp. 497-518. ISSN 0165-1587. DOI 10.1093/erae/27.4.497.

[23] Latruffe, L., Bravo-Ureta, B. E., Moreira, V. H., Desjeux, Y. and Dupraz, P. (2011) "Productivity and Subsidies in European Union Countries: An Analysis for Dairy Farms Using Input Distance Frontiers", Paper presented on the $12^{\text {th }}$ congress of European Association of Agricultural Economists, $30^{\text {th }}$ August-2 ${ }^{\text {nd }}$ September 2011, Zürich, Switzerland.

[24] Luik, H., Omel, R. and Viira, A.-H. (2011) "Efficiency and productivity change of Estonian dairy farms from 2001-2009“, The article presented at congress EAAE: Change and Uncertainty Challenges for Agriculture, Food and Natural Resources, 30.8.-2.9.2011, ETH Zurich, Zurich, Švýcarsko.

[25] Madau, F. A., Furesi, R. and Pulina, P. (2017) "Technical efficiency and total factor productivity changes in European dairy farm sector", Agricultural and Food Economics, Vol. 5, No. 17, pp. 1-14. ISSN 2193-7532. DOI 10.1186/s40100-017-0085-x.

[26] Morrison Paul, C., Nehring, R., Banker, D. and Somwaru, A. (2004) “Scale Economies and Efficiency in U.S. Agriculture: Are Traditional Farms History?", Journal of Productivity Analysis, Vol. 22, No. 3, pp. 185-205. ISSN 0895-562X. DOI 10.1007/s11123-004-7573-1.

[27] Newman, C. and Mathews, A. (2007) "Evaluating the Productivity Performance of Agricultural Enterprises in Ireland using a Multiple Output Distance Function Approach“, Journal of Agricultural Economics, Vol. 58, No. 1, pp. 128-151. ISSN 1477-9552. DOI 0.1111/j.1477-9552.2007.00084.x.

[28] Rasmussen, S. (2011) "Estimating the Technical Optimal Scale of Production in Danish Agriculture", Paper presented on the $12^{\text {th }}$ congress of European Association of Agricultural Economists, $30^{\text {th }}$ August- $2^{\text {nd }}$ September 2011, Zürich, Switzerland.

[29] Sipiläinen, T., Kumbhakar, S. C. and Lien, G. (2014) "Performance of dairy farms in Finland and Norway from 1991 to 2008", European Review of Agricultural Economics, Vol. 41, No. 1, pp. 63-86. ISSN|0165-1587. DOI 10.1093/erae/jbt012.

[30] Skevas, I., Emvalomatis, G. and Brümmer, B. (2018) "Heterogenity of Long-run Technical Efficiency of German Dairy Farms: A Bayesian Approach”, Journal of Agricultural Economics, Vol. 69, No. 1, pp. 58-75. ISSN 1477-9552. DOI 10.1111/1477-9552.12231.

[31] Špička, J. and Machek, O. (2015) "Change in the production efficiency of European specialized milk farming“, Agricultural Economics - Czech, Vol. 61, No. 1, pp. 1-13. ISSN 1805-9295. DOI 10.17221/112/2014-AGRICECON.

[32] Wojciechowski, L. (2017) "Productivity Gap: A Chance or an Obstacle in Absorbing Benefits from FDI in a Host Country“, Entrepreneurial Business and Economics Review, Vol. 5, No. 4, pp. 153-170. ISSN 2353-8821. DOI 10.15678/EBER.2017.050407.

[33] Zhu, X. and Lansink, A. O. (2009) "Determinants of productivity change of crop and dairy farms in Germany, the Netherlands and Sweden in 1995-2004", Paper presented at the International Association of Agricultural Economists Conference, 16.8.-22.8.2009, Beijing, China.

[34] Žáková Kroupová, Z. (2016) "Profitability development of Czech dairy farms", Agricultural Economics-Czech, Vol. 62, pp. 269-279. ISSN 1805-9295. DOI 10.17221/131/2015-AGRICECON. 